\title{
MICROORGANISMS FOUND IN FAST AND TRADITIONAL FAST FOODS
}

\author{
(Received:18.10.2010)
}

\author{
By \\ S. M. H. Easa \\ Microbiology Department, Faculty of Science, Ain Shams University, Cairo, Egypt
}

\begin{abstract}
Sixty food samples were collected from 60 random restaurants of fast and traditional foods in El Qassium, Saudi Arabia and investigated for the presence of bacteria using different temperatures $\left(10^{\circ} \mathrm{C}\right.$, $20^{\circ} \mathrm{C}, 30^{\circ} \mathrm{C}, 40^{\circ} \mathrm{C}$ and $50^{\circ} \mathrm{C}$ ) incubated for $24-48$ hours and analyzed for fungi and yeasts incubated at $25^{\circ} \mathrm{C}$. The results revealed that from 45 samples of traditional foods, twenty two species of eighteen genera of bacteria were found plus fourteen species of twelve genera of fungi and three species of three genera of yeasts. While fast food results revealed that from 15 fast food samples collected from 15 restaurants a total of ten species of ten genera of bacteria and eight species of seven genera of fungi were recorded. The species of bacteria isolated in this study are, Acetobacter sp., Achromobacter sp., Bacillus coagulans, B. subtilis, Clostridium perfringens, Erwinia carotovora, Escherichia coli, Flavobacterium sp., Klebsiella pneumoniae, Lactobacillus plantarum, Leuconostoc mesenteroides, Listeria monocytogenes, Microbacterium lacticum, Micrococcus sp., Pseudomonas aeruginosa, Pseudomonas fluorescens, Pseudomonas putrefaciens, Salmonella sp., Staphylococcus aureus, Streptococcus lactis, Streptococcus thermophilus, Campylobacter jejuni, Citrobacter fruendii, Proteus vulgaris and Yersinia sp. The occurrence of some of these bacteria illustrates that fast foods in these restaurants may act as a reservoir of pathogenic bacteria for human. Fungi isolated are Aspergillus glaucus, A. niger, Alternaria sp., Chaetomium candidum, Cladosporium herbarum, Fusarium sp., Monilia sp., Mucor rouxii, Neuropora sp., Penicillium expansum, Penicillium sp., Rhizopus nigricans, Sporotrichum carnis and Thamnidium elegans. Yeasts were represented by Torulopsis caroliniana, Saccharomyces rouxii and Zygosaccharomyces sp. Total viable count of bacteria (CFU) was higher in foods containing vegetable salad and fresh vegetables than heated foods (e.g., chicken Shawirma, Beef burger). Some bacteria resist heat and grow at $50^{\circ} \mathrm{C}$. Contamination occurred through raw foods, use of polluted irrigation waters, human handling and the use of contaminated containers. The binge-eating of fast food can lead to measurable signs of liver injury, inflammation and inexpensive fat-and calorie-packed foods make us the fat. Food poisoning can be controlled by the adjustment of $\mathrm{pH}$, water activity, temperature control. Prevention of toxins in fast foods must become a cooperative effort on the part of all involved in food production. Prevent multiply the microorganisms by washing and dry hands before preparing any foods and after handling raw foods (meat, poultry, vegetables or fruits), food preparation areas, equipment must be cleaned, kitchen areas, restaurants and foods protected from insects, pests and other animals. Patients should not handle foods in restaurants.
\end{abstract}

Key words: bacteria, contamination, fast food, fungi, poisoning food, temperatures, traditional fast food, yeasts.

\section{INTRODUCTION}

Food is a chemically complex matrix, and predicting whether, or how fast, microorganisms will grow in any given food is difficult. Most foods contain sufficient nutrients to support microbial growth. Several factors encourage, prevent, or limit the growth of microorganisms in foods, the most important are water availability, $\mathrm{pH}$, and temperature (Makukutu and Guthrie, 1986; Smith and Fratamico, 1995 and ICMSF, 1996).
The busy and hectic life schedule has opened the way for the fast food industry in most parts of the world. The traditional or conventional way of cooking is over and the fast food joints are visible everywhere. Fast food does not only include the traditional fast food items like pizza, burger or French fries but it also includes Chinese as well as Indian. The most typical fast food meals eaten in Germany are similar to those eaten in America namely burger, pizza and fries. Other popular meals 
are (a sliced sausage with ketchup and mayonnaise), Kebab (the meat is served in flatbread along with lettuce, onion, cucumber, tomatoes) (Ockerman and Stec, 1980; El-Sherif et al., 1991). Although fast food restaurants are often viewed as a representation of modern technology, the concept of "ready-cooked food to go" is as old as cities themselves; unique variations are historical in various cultures. Ancient Roman cities had bread-and-olive stands, flat bread and falafel are ubiquitous in the Middle East. Food habits, pattern and behavior vary widely from culture to culture. Popular Saudi Arabian traditional foods include meat, rice, wheat, vegetables and spices that give these recipes a special flavor.

There are many popular foods in Saudi Arabia like Jarish, Qursan, Saliq, Masapep, Keshta, Mataziz, Freek, Hunayni and Harisah.

In recent years just about all the quick service restaurants have added salad fresh vegetables (Lettuce, Cabbage, Carrot, Cucumber, Onion, ketchup, maymonise). Some foods are cooked prior to consumption others are eaten raw. Products that might be classed with both fresh and processed vegetables are the chopped salad ingredients sold in the grocery store and to the institutional trade. Although essentially fresh, contamination during processing, and changes in microbial growth patterns during storage, may later lead to microflora of these foods quantitatively and qualitatively. The inner tissues of healthy plants and animals are free of microorganisms. However, the surfaces of raw vegetables and meats are contaminated with a variety of microorganisms and this depends on the condition of the raw product, the method of handling, and the time and conditions of storage (Woodward , 1996; Odumeru et al., 1997 and Pelczar et al., 2006).

Microbial food safety is an increasing public health concern worldwide. It is estimated that each year in the United States there are approximately 76 million food borne illnesses. Cases are caused by Campylobacter species, nontyphoidal Salmonella, pathogenic Escherichia coli and all colonize the gastrointestinal tracts of a wide range of wild and domestic animals, especially animals raised for human consumption (Meng and Doyle, 1998). Food contamination with these pathogens can occur at multiple steps along the food chain, including production, processing, distribution, retail marketing and handling or preparation. Numerous epidemiological reports have implicated foods of animal origin as the major vehicles associated with illnesses caused by food-borne pathogens (Petersen and James, 1998).

Contaminated raw or undercooked poultry and red meats are particularly important in transmitting food borne pathogens. Other sources of human infections include contaminants produced by contact with farm animals and pets. Person-to person transmission has also been described. These microorganisms are carried on hands, wiping cloths and utensils, especially choping boards. The slightest contact can transfer them to food and cause food borne diseases. Examples of zoonotic pathogens that may be transmitted in this way include Salmonella, Campylobacter, Escherichia coli and eggs of the tape worm, Taenia solium (Meng and Doyle, 1998).

The gut is the most important source of bacteria, contributing Clostridium perfringens, coliforms, Salmonella and Staphylococcus to the meat surface. Mesophiles, including pathogens, cannot grow on chilled carcasses, but psychrotrophs of the Pseudomonas, Achromobacter grow readily, and eventually spoil the meat (Meng and Doyle, 1998). The conditions in a well wrapped piece of meat encourage the growth of the Lactobacillus at the expese of the Pseudomonas, Achromobacter group (Petersen and James, 1998).

Pathogenic microorganisms on raw vegetables and fruits suggested that the use of poor quality water for irrigation could increase the incidence of enteric pathogens (E. coli)., Erwinia spp., Aeromonas, Serratia spp. and some gram negative bacteria (Pseudomonas spp., Citroacter freundii) and Clostridium and Xanthomonas, Staphylococcus aureus, Corynebacterium, Listeria spp., Lactobacillus spp., Streptococcus spp. and Micrococcus spp., as gram positive bacteria. The consumption of fast foods, raw milk and raw milk products have been reported to be associated with serious health problems (De Boer and Hahne, 1990; Pacini et al., 1997; Food and Drug Administration (FDA), 2000, 2010 and Pelczar et al., 2006).

Microorganisms in fast and traditional foods are responsible for many human diseases. e.g., Salmonella bacteria are common cause of food borne illness, particularly in undercooked chicken and chicken eggs (Woodward, 1996; Kaneko et al., 1999 a; Uyttendaele et al., 1999 and Angelillo et al., 2000).

However, some studies suggested the incidence of Listeria sp. in retail foods, ready-cooked chicken, on the hands of food workers, food stuffs, human faeces, sewage and soil from urban sources (MacGowan et al., 1994).

Furthermore, it was reported the prevalence of Campylobacter spp., Staphylococcus spp., Escherichia coli, Salmonella spp., Yersinia spp. and Listeria on meat, sea foods, vegetable ingredients, chicken shawirmas, raw and cooked foods, raw 
chicken, beef burger sandwiches, ready-to eat salad vegetables, commercial Mayonnaise, frozen chicken, poultry products and on the hands of food workers (Kaneko et al., 1999b and Pelczar et al., 2006).

Uzeh et al. (2009) reported that microorganisms isolated from salad containing raw vegetables include Mucor sp., Aspergillus fumigatus, Trichoderma, Neurospora crassa and Aspergillus niger.

It was investigated that fast food contains high levels of refined sugar, white flour, trans fat and polyunsaturated fat, salts and numerous food additives, at the same time it is lacking in proteins, vitamins and fibers. Consumption of fast food in the world has been associated with obesity leading to many diseases (Canadian Institute for Health Information, 2007).

Raw materials, including water, ice and milk, may be contaminated with dangerous microorganisms. Toxic chemicals may be formed in damaged and mouldy foods. Care in selection of raw materials and simple measures such as washing and peeling, may reduce the risk. Contaminated water, for example, has been associated with outbreaks of Salmonella, Campylobacter and Escherichia coli, whilst infections with Salmonella, Campylobacter, Mycobacterium (TB), Brucella and Escherichia coli can be acquired through the consumption of contaminated milk or dairy products that are not pasteurized (Meng and Doyle, 1998). When raw milk is left standing for a while, it turns "sour" this is the result of fermentation, where lactic acid bacteria ferment the lactose inside the milk into lactic acid. Prolonged fermentation may render the milk unpleasant to consume. This fermentation process is exploited by the introduction of bacterial cultures (e.g., Lactobacillus sp., Streptococcus sp., Leuconostoc sp. ...etc) to produce a variety of fermented milk products. The reduced $\mathrm{pH}$ from lactic acid accumulation denatures protein and caused the milk to undergo a variety of different transformations in appearance and texture (Deak and Beuchat, 1996). Fast foods are sold in a restaurant or store with low quality preparation and served to the customer in a packaged form for take out/take away. In most fast food operations, menu items are generally made from processed ingredients prepared at a central supply facility and then shipped to individual outlets where they are reheated, cooked (usually by microwave or deep frying) or assembled in a short amount of time. Fast foods are often very high in calories, saturated fat and sodium that can make us fat, clog our arteries and send our blood pressure soaring. Food substances that have been prepared by a fermentative process, or have been exposed to microbial contamination during aging or storage, are likely to contain amines. Alcoholic beverages such as beers can contain biogenic amines, as do some other fermented foods such as sauerkraut and soy bean products (Sanchez, 2009). Amines are also considered as endogenous plant substances that are commonly used for food, where some vegetables and fruits were found to contain high concentrations of various amines. The biogenic amine contents of various foods and feed have been widely studied and found in cheese, fish, meat products, eggs and mushrooms. Biogenic amines may also be considered as carcinogens because of their ability to react with nitrites to form potentially carcinogenic nitrosamines. The toxicity of biogenic amines to chicks in terms of loss of weight and mortality was also reported (Heaton and Jones, 2008).

Meat, produce and soft cheeses (e.g., brie cheese, cottage cheese) have more water content, allowing any bacteria, viruses or molds present to multiply quickly (Bichai et al., 2008).

It was suggested that food must be cooked thoroughly to the correct temperature because proper cooking kills almost all dangerous microorganisms. Studies have shown that cooking food to a temperature of $70^{\circ} \mathrm{C}$ can help ensure that it is safe for consumption, for example poultry, minced meat products (e.g., hamburger and sausages). Ideally, the center of the food should reach a temperature of $70^{\circ} \mathrm{C}$ for at least two minutes (Makukutu and Guthrie, 1986). Chilled, ready to eat foods must be kept to temperature below $5^{\circ} \mathrm{C}$. Hot foods must be kept at temperatures above $60^{\circ} \mathrm{C}$ before serving. Cool rapidly and refrigerate left over foods if they are not to be used within 2 hours. Food should be cold before placing in the refrigerator since it may take a while to cool off in the refrigerator and hot food may warm up other foods (Kaneko et al., 1999 b). Some of the highest aerobic counts have been reported for tubers and other vegetables that are in contact with the soil e.g., lettuce, carrots, potatoes, cabbage and flafel with fresh vegetable salads record the highest count of microorganism (Kaneko et al., 1999 a). The high acid and sugar content of fruits often permits yeasts and molds to predominate, while the high carbohydrate content of many vegetables favors the lactic acid bacteria. It was reported that the major source of the organisms on frozen vegetables is contaminated equipment; such as chopers, slicers, conveyor and inspection belts, and filling machines. Some of these units possess surfaces that are difficult to reach for proper 
cleaning. Belts may present problems because of the tenacity with which organisms adhere to certain surfaces, and because some fabrics absorb moisture and thus permit a microbial build up within the belt interior. Many organisms do not survive in a low $\mathrm{pH}$ environment; for example, Salmonella and Shigella die off rapidly in citrus juices (Norberg, 1981).

Contamination of the egg shells occurs after laying nesting material, dirt, and fecal matter. It was reported that the flora of egg shells are dominated by gram positive cocci while the gram negative rods are present in numbers. The eggs may contain organisms from the shell surface by improper washing and storage methods. The most common genera of bacteria found in liquid eggs are gram negative types, including Pseudomonas, Proteus and Escherichia. In commercial egg breaking operations the egg shell is a source of contamination and may contribute large numbers of gram positive cocci to the liquid egg (Administration Urged to Boost Food Safety, 2009). Colonization of the shell contents is characterized by a mixed flora of gram negative bacteria. The most common contaminants are the coliforms, Achromobacter, Pseudomonas, Serratia, Proteus, Alcaligenes and Citrobacter (Finegold and Martin, 1982; Uyttendaele et al., 1999). The major pathogen associated with eggs and egg products is Salmonella.

Some meat products such as flame seared beef patties and cooked beef are processed at lower temperatures. These temperatures are sufficient to destroy pathogens, but the final bacterial counts include some of the more heat resistant vegetative bacteria such as the enterococci. Unless cooked products are packaged hot and immediately frozen, recontamination invariably occurs from equipment, food handlers, raw products or dust (Angelillo et al., 2000).

Human health and mycotoxicoses: It was reported that the ubiquitous fungal strains involved could utilize wide variety of foodstuffs for toxin production. Several mycotoxins have been verified as naturally occurring foods and feeds (Barnett et al., 2000). Most mycotoxicoses of man or animals have been recognized by observation of the toxicity of moldy foods and feeds. The toxigenic storage fungi are primarily Aspergillus, Penicillium, while some like Fusarium may be either field or storage organisms. The mycotoxins presently considered to present the most potential for human health hazard are the toxins of the storage fungi in the genera, Aspergillus, Penicillium and Fusarium are those elaborating mycotoxins which are more important in foods and feeds.

Some of the mycotoxin findings reported represent extensive survey, others are very limited. Fungi, such as the moulds commonly seen on bread, can also cause illness while viruses such as hepatitis may also be food borne (Wart, 1989). It was reported that when foods such as meat, spaghetti sauce or vegetables are canned, the oxygen can not get in therefore growth of aerobic organisms is controlled and the food is preserved. Some microorganisms will grow only in anaerobic conditions. Botulism is a rare type of food borne illness caused by microorganism that prefers anaerobic conditions. Home canned food that have not been preserved properly are the most common source of this type of food borne illness (Kao and Shih, 1993 and Pacini et al., 1997).

The objectives of this study were to determine the presence of pathogenic bacteria, fungi and yeasts in fast and traditional foods in some restaurants causing human diseases, as well as to investigate the association of microbial contamination with component, type, temperature, season of foods. This study was carried out to give information about the methods of prevention of diseases due to food borne pathogens and how to control it.

\section{MATERIALS AND METHODS}

Sixty restaurants were tested in the present study. Fast and traditional food samples were obtained from fast and traditional fast food restaurants in $\mathrm{El}$ Qassim, Saudi Arabia in the Summer (2007). The Centers for Disease Control Food Borne Diseases Active Surveillance Network (Food net) data indicate that outbreaks and clusters of food-borne infections peak occur during the warmest months of the year (Centers for Disease Control and Prevention, 2001).

2.1. Samples of foods: A) Traditional foods: The traditional fast foods which were used in the research: 1. Jarish: composed of animal fats, crushed wheat, oil, salts and apices. Jarish may be simply boiled and served with a topping of chopped hot pepper and onion or it may be browned in butter or oil and then cooked into a sort of pilaf with a chunks of meat, chopped onion and tomato for the richly flavored dish. 2. Mataziz: composed of flour, meat, cucurbita, onion, oil, spices, tomato and salt. 3 . Qursan: included meat, oil, different vegetables onion, tomato, limon and salt. 4. Keshta: included of palm, butter and flour. 5. Mathbib: contained eggs, oil, flour, salt and sugar. 6. Freek: composed of eggs, flour, sugar, small amount of salt. 7. Hunayni: included palm, bread, butter, spices and water. 8. Saliq: contains chicken, rice, milk and spices. The rice first half cooked in meat or chicken both and then with milk for one hour. 
9. Harees: composed of meat, sugar, butter, wheat, salt and cinnamum zeylani.

B) Fast foods: 1. Chicken shawrmas with salads. 2. Hamburger (beef burger) with salads. 3. Flafel with salads (lettuce, tomato, onion, cucumber).

2.1.1. Collection of samples: Sixty samples were obtained from 60 restaurants at a temperature $35^{\circ}$ $37^{\circ} \mathrm{C}$ in the summer(2007). The food samples were taken from restaurant in sterile plastic bags in IceBox, according to Cheesbrough (1984).

2. 1.2. Preparation of food samples: From each sample $25 \mathrm{~g}$ was aseptically weighed and macerated and $225 \mathrm{mls}$ of sterile distilled water was added. Serial dilution was carried out using sterile distilled water as diluents. From each dilution $1 \mathrm{ml}$ was plated using the pour plate methods of Swanson et al. (1992).

\subsubsection{Isolation of Microorganisms}

A) Isolation of Bacteria: Samples were cultivated on different media. The inoculated media were cultured at different temperatures. Pure cultures of the microorganisms were identified using the standard procedures of Barrow and Feltham (1993). The tests employed for the identification of isolates were the Gram stain, biochemical test, pigments and colony morphology.

The streak plate method was used for the recovery of the various bacteria species. The Total Viable Count (TVC) of bacteria species was done on different media. The inoculated plates of bacteria were incubated at different temperatures $\left(10^{\circ} \mathrm{C}\right.$, $20^{\circ} \mathrm{C}, 30^{\circ} \mathrm{C}, 40^{\circ} \mathrm{C}$ and $50^{\circ} \mathrm{C}$ ) for $24-48$ hours. The colony forming units (CFU) were counted with a Gallenkamp colony counter, the result reported as (CFU) per $\mathrm{ml}$ of sample. The same process was repeated in respect of fungi and yeasts, which were incubated at $\left(25-30^{\circ} \mathrm{C}\right)$.

\subsection{The culture media}

2.2.1.Nutrient agar medium: was used for total bacterial count (enumeration of bacteria). The medium contained $3.0 \mathrm{~g}$ beef extract and $5.0 \mathrm{~g}$ peptone (per liter of distilled water) according to Atlas (1993) and Swanson et al. (1992).

2.2.2.MacConkey agar medium: it is a differential and low selectivity medium used to distinguish lactose fermenting (e.g, Klebsiella and Esherichia coli) from non lactose fermenting bacteria (Pseudomonas aeruginosa, Salmonella species and Proteus mirabilis (Oxoid 1992).

2.2.3.Salmonella-Shigella agar medium: was used for isolation of Salmonella and Shigella species and the cultures were incubated at $35^{\circ} \mathrm{C}$ for $24-48$ hours (Feng et al., 2007).

2.2.4.Violet red bile agar: was used to distinguish coliform bacteria, and Eosin-Methylene blue Agar (EMB) was used for the isolation of Escherichia coli (Oxoid, 1992).

2.2.5.Mannitol salt agar: it is a differential and selective plate medium used to isolate Staphylococcus aureus, the medium is available in dehydrated form from Oxoid Ltd. Mannitol is fermented by Staphylococcus aureus (yellow in medium) (Finegold and Martin, 1982).

2.2.6.Staphylococcus medium (No.110):

Staphylococcus medium was used for the isolation of Staphylococcus spp. and Micrococcus spp. (G+ bacteria) according to Matthews et al. (1997).

2.2.7.Rosef broth: Campylobacter strains were grown in stationary cultures in $5 \mathrm{ml}$ of Rosef broth without antibiotics for 48 hours in microaerophilic atmosphere created by using BBL gas peak plus microaerophilic system envelops without the palladium catalyst (Ryan and Ray, 2004).

Clostridium perfringers isolates were grown in a stationary culture in an anaerobic atmosphere and subsequently diluted in sterile Rosef broth or sterile saline to concentrations of $10^{6}$ to $10^{8} \mathrm{CFU}$ per ml (Baumgart et al. 2007).

1. MRS Broth (de Man, Rogosa and Sharpe): Lactobacilli bacteria were counted with M.R.S. agar medium according to (Laner and Kandier, 1980). After incubation, colonies developed on the plate were counted. The plates with between 30 and 300 colony recorded as colony forming units [total viable count $(\mathrm{CFU} / \mathrm{ml})]$. Pure cultures of the isolates were obtained by subsequent sub culturing on fresh agar plates.

\section{Identification of microbial isolates:}

Isolates of bacteria were identified by the API for enterobacteriaceae only system following the method adapted by Collins et al. (1995). This was done based on cultural, morphological and biochemical characteristics of the isolates, the method of bacterial classification, was the Gramstaining stain method, as described by Barrow and Feltham (1993) and identification according to Krieg and Holt (1984) and Sneath et al. (1989).

\subsection{Isolation and identification of fungi}

The purpose of screening was to isolate potent pure cultures from different samples of fast and traditional foods. Test-samples were plate on the surface using the dilution plate method Swanson et al. (1992) using (1) Sabourauds Dextrose agar (SDA) (2) Potato Dextrose agar (PDA). Identification to the genus level was carried out throughout macroscopic and microscopic examination, followed by more accurate identification to the species level according to John 
and Pitt (1979), Domsch et al. (1993) and Robert et al. (2008).

2.4. Isolation of yeasts: Yeats were isolated from samples of traditional and fast foods by using the dilution plate method of Swanson et al. (1992), media used were (1) Peptone Yeast Malt Agar (PYM), (2) Dextrose-Yeast Broth (DYB), (3) Nutrient agar (NA). Yeast isolates were identified according to Arx (1981); Barnett et al. (2000).

Statistical analysis:

Statistical analysis was carried out using statistical program SAS (1988). Duncan's multiple range test was used to separate means.

\section{RESULTS}

\subsection{Microorganisms isolated from traditional food samples}

The results of isolation of some species of microorganisms from 60 food samples collected from 60 different restaurants at El Qasim revealed that, a total of the bacteria isolated from traditional foods include Acetobacter species, Achromobacter species, Bacillus coagulans, Bacillus subtilis, Clostridium perfringens, Escherichia coli, Erwinia carotovora, Flavobacterium species, klebsiella pneumoniae, Lactobacilus plantarum, Lactobacllus species, Listeria monocytogenes, Micrococcus species. Microbacterium lacticum, Proteus vulgaris Pseudomanas aeruginos, P. fluorescens, Pseudomonas putrefaciens, Staphylococcus aureus, Streptococcus lactis, Streptococcus thermophilus and Leuconostoc mesenteroides. While from fast foods: bacteria isolated include Campylobacter jejuni,Citrobacter fruendii, Bacillus subtilis, Escherichia coli, Listeria monocytogenes, proteus vulgaris, pseudomonas aerginosa, Staphylococcus aureus, Salmonella species and Yersinia species. The bacterial isolates were recorded in Tables $(1,2$ and 3).

(2) Bacteria isolated from fast food samples: The results of isolation of bacteria from 15 fast food samples collected from 15 restaurants at El Qassim revealed that ten genera were identified (Table 4).

3.2. Effect of different temperatures on isolated bacteria: The occurrence of isolated bacteria at different temperatures (from traditional foods and fast foods) at $10^{\circ} \mathrm{C}, 20^{\circ} \mathrm{C}, 30^{\circ} \mathrm{C}, 40^{\circ} \mathrm{C}$ and $50^{\circ} \mathrm{C}$ are found in (Tables 5 and 6 ).

3.3. Fungal species from fast food samples: The results of isolation of fungi from 15 fast food samples collected from 15 restaurants revealed that eight species of seven genera were isolated (Table 7) and this agree with Pelczar et al. (2006). foods: In the present study the restaurants were chosen because of people in these localities are more exposed to pathogenic fungi, bacteria, yeasts which may be transmitted to them from foods, soil or hands of workers and also from person to another. The total bacterial count was higher in food samples (Mathabib, Jarish and Qursan) than those from Hunayni and Mataziz, Keshta. While the total bacterial count was lower in food samples Keshta (Freek and Saliq) and the lowest number was in Harees (Table 8).

Table (1) shows the bacteria isolated from traditional foods include Acetobacter species, Achromobacter species, Bacillus coagulans, Bacillus subtilis, Clostridium perfringens, Escherichia coli, Erwinia carotovora, Flavobacterium species, Klebsiella pneumoniae, Lactobacillus plantarum, Lactobacillus species, Listeria monocytogenes, Micrococcus species, Microbacterium lacticum, Proteus vulgaris, Pseudomonas aeruginosa, $P$. fluorescens, Pseudomonas putrefacien, Staphylococcus aureus, Streptococcus lactis, Streptococcus thermophilus and Leuconostoc mesenteroides.

3.5. The total bacterial count from fast foodsBacteria of this group of fast food samples may cause disease to human. Isolated bacteria included Campylobacter jejuni, Citrobacter fruendii, Bacillus subtilis, Escherichia coli, Listeria monocytogenes, Proteus vulgaris, Pseudomonas aeruginosa, Staphylococcus aureus, Salmonella species, and Yersinia species (Tables 4 and 9).

On the other hand, we can divide the isolated bacteria from fast and traditional food samples into:

3.5.1.Gram negative bacteria: isolated from traditional foods and fast foods are: Campylobacter jejuni, Escherichia coli, Klebsiella pneumoniae, Salmonella species, Yersinia species, Proteus vulgaris, Acetobacter species, Flavobacterium species, Pseudomonas aeruginosa, Citrobacter freundii, Erwinia carotovora, Pseudomonas fluorescens, Pseudomonas putrefaciens, Achromobacter species.

3.5.2.Gram positive cocci: Isolated from traditional foods and fast foods are: Luconostoc mesenteroides, Micrococcus species, Staphylococcus aureus, Streptococcus Lactis and Streptococcus thermophilus.

3.5.3.Gram positive non sporing rode: Listeria monocytogenes and Lactobacilli plantarum were isolated from traditional foods and fast foods. 
Table (1): Bacterial species isolated from traditional foods.

\begin{tabular}{|c|c|l|}
\hline No. & Name of Sample & \multicolumn{1}{c|}{ Types of bacteria isolated from samples } \\
\hline 1 & Jarish & Escherichia coli, Lactobacillus plantarum, Pseudomonas putrefaciens, Streptococcus thermophilus. \\
\hline 2 & Mataziz & $\begin{array}{l}\text { Acetobacter species, Erwinia carotovora, Micrococcus species, Pseudomonas aeruginosa, Staphylococcus aureus, } \\
\text { Clostridium perfringens }\end{array}$ \\
\hline 3 & Qursan & Acetobacter species, Escherichia coli, Pseudomonas aeruginosa, Erwinia carotovora, Lactobacillus species. \\
\hline 5 & Keshta & Klebsiella pneumoniae, Micrococcus sp., Staphylococcus aureus \\
\hline 5 & Mathabib & $\begin{array}{l}\text { Bacillus subtilis, Flavobacterium species, Klebsiella pneumoniae, Micrococcus sp., Pseudomonas aeruginosa, } \\
\text { Microbacterium lacticum, Leuconostoc mesenteroides. }\end{array}$ \\
\hline 6 & Freek & $\begin{array}{l}\text { Bacillus subtilis, Listeria monocytogenes, Proteus vulgaris, Micrococcus species, Shewanella (Pseudomonas) } \\
\text { putrefaciens, Staphylococcus aureus. }\end{array}$ \\
\hline 8 & Hucillus coagulans, Micrococcus species, Pseudomonas fluorescens, Staphylococcus aureus \\
\hline 9 & Saliq & $\begin{array}{l}\text { Escherichia coli, Listeria monocytogenes, Lactobacillus plantarum, Micrococcus } \text { species, Achromobacter } \text { species, } \\
\text { Staphylococcus aureus, Streptococcus lactis. }\end{array}$ \\
\hline
\end{tabular}

Table (2): Fungal species isolated from traditional foods.

\begin{tabular}{|c|c|l|}
\hline No. & Name of Sample & \multicolumn{1}{c|}{ Fungal species } \\
\hline 1 & Jarish & Aspergillus niger, Alternaria species, Fusarium species, Neurospora species. \\
\hline 2 & Mataziz & Penicillium expansum, Chaetomium candidum. \\
\hline 3 & Qursan & Aspergillus glaucus, Penicillium expansum, Neurospora species, Chaetonium candidum, Mucor rouxii, Alternaria species. \\
\hline 4 & Keshta & Penicillium expansum, Rhizopus nigricans \\
\hline 5 & Mathabib & Aspergillus niger, Cladosporium herbarum, Penicillium species. \\
\hline 6 & Freek & Aspergillus glaucus, Cladosporium herbarum, Monilia species, Rhizopus nigricans \\
\hline 7 & Hunayni & Alternaria species,Thamnidium elegans \\
\hline 8 & Saliq & Sporotrichum carnis, Penicillium species. \\
\hline 9 & Harees & Alternaria species, Penicillium species. \\
\hline
\end{tabular}


Table (3): Yeast species isolated from traditional foods.

\begin{tabular}{|c|c|l|}
\hline No. & Name of sample & \multicolumn{1}{|c|}{ Yeast species } \\
\hline 1 & Jarish & Torulopsis caroliniana. \\
\hline 2 & Mataziz & ND. \\
\hline 3 & Qursan & Torulopsis caroliniana. \\
\hline 4 & Keshta & $\begin{array}{l}\text { Saccharomyces rouxii, } \\
\text { Zygosaccharomyces species. }\end{array}$ \\
\hline 5 & Mathabib & Torulopsis caroliniana. \\
\hline 6 & Freek & Torulopsis caroliniana. \\
\hline 7 & Hunayni & Saccharomyces rouxii, Torulopsis caroliniana. \\
\hline 8 & Saliq & Torulopsis caroliniana, Saccharomyces rouxxi. \\
\hline 9 & Harees & Torulopsis caroliniana. \\
\hline
\end{tabular}

Table (4): Bacterial species isolated from different fast foods.

\begin{tabular}{|l|l|c|}
\hline \multicolumn{1}{|c|}{ Type of sample } & \multicolumn{3}{c|}{ Bacteria isolated from samples } \\
\hline Chicken Shawirmas & $\begin{array}{l}\text { Campylobacter jejuni, Escherichia coli, Listeira } \\
\text { monocytogenes, Salmonella species. }\end{array}$ \\
\hline Hamburger (beef burger) & $\begin{array}{l}\text { Listeria monocytogenes, Salmonella species, } \\
\text { Staphylococcus aureus, Yersinia species. }\end{array}$ \\
\hline Flafel with salads (Lettuces, Tomato, Cucumber) & $\begin{array}{l}\text { Campylobacter jejuni, Escherichia coli, Listeria } \\
\text { monocytogenes, Salmonella species, Pseudomonas } \\
\text { aeruginosa, Citrobacter fruendii, Proteus vulgaris, } \\
\text { Bacillus subtilis }\end{array}$ \\
\hline
\end{tabular}

Table (5): Occurrence of bacteria at different temperatures isolated from traditional foods obtained from different restaurants.

\begin{tabular}{|c|c|c|c|c|c|c|}
\hline \multirow{2}{*}{ No. } & \multirow{2}{*}{ Bacterial species } & \multicolumn{5}{|c|}{ Temperature } \\
\hline & & $10^{\circ} \mathrm{C}$ & $20^{\circ} \mathrm{C}$ & $30^{\circ} \mathrm{C}$ & $40^{\circ} \mathrm{C}$ & $50^{\circ} \mathrm{C}$ \\
\hline 1 & Acetobacter species & - & + & + & - & - \\
\hline 2 & Acrhomobacter species & + & + & - & - & - \\
\hline 3 & Bacillus coagulans & - & + & + & + & + \\
\hline 4 & Bacillus subtilis & + & + & + & + & + \\
\hline 5 & Clostridium perfringens & - & - & - & - & + \\
\hline 6 & Erwinia carotovora & - & + & + & + & - \\
\hline 7 & Escherichia coli & + & + & + & + & - \\
\hline 8 & Flavobacterium species & + & + & + & - & - \\
\hline 9 & Klebsiella pneumoniae & - & + & + & + & - \\
\hline 10 & Lactobacillus plantarum & + & + & + & - & - \\
\hline 11 & Lactobacillus species & + & + & + & - & - \\
\hline 12 & Leuconostoc mesenteroides & - & + & + & - & - \\
\hline 13 & Listeria monocytogenes & + & + & + & + & - \\
\hline 14 & Microbacterium lacticum & - & + & + & + & + \\
\hline 15 & Micrococcus species. & + & + & + & + & - \\
\hline 16 & Proteus vulgaris & - & - & - & - & + \\
\hline 17 & Pseudomonas aeruginosa & - & + & + & + & - \\
\hline 18 & Pseudomonas fluorescens & + & + & - & - & - \\
\hline 19 & Shewanella(Pseudomonas) putrefaciens & + & + & + & + & - \\
\hline 20 & Staphylococcus aureus & + & + & + & + & + \\
\hline 21 & Streptococcus lactis & + & + & + & - & + \\
\hline 22 & Streptococcus thermophilus & - & + & + & + & + \\
\hline
\end{tabular}


Table (6): Occurrence of bacteria at different temperatures isolated from fast foods obtained from different restaurants

\begin{tabular}{|c|l|c|c|c|c|c|}
\hline \multirow{2}{*}{ No. } & \multirow{2}{*}{ Isolated bacterial species } & \multicolumn{5}{|c|}{ Temperature } \\
\cline { 3 - 7 } & & $\mathbf{1 0}^{\mathbf{}} \mathbf{C}$ & $\mathbf{2 0}^{\mathbf{}} \mathbf{C}$ & $\mathbf{3 0}^{\mathbf{}} \mathbf{C}$ & $\mathbf{4 0}^{\mathbf{}} \mathbf{C}$ & $\mathbf{5 0}^{\mathbf{}} \mathbf{C}$ \\
\hline 1 & Campylobacter jejuni & - & + & + & + & - \\
\hline 2 & Escherichia coli & - & + & + & + & - \\
\hline 3 & Listeria monocytogenes & + & + & + & + & - \\
\hline 4 & Salmonella species. & - & - & + & + & - \\
\hline 5 & Staphylococcus aureus & - & + & + & + & - \\
\hline 6 & Pseudomonas aeruginosa & + & + & + & + & - \\
\hline 7 & Citrobacter fruendii & - & + & + & + & - \\
\hline 8 & Proteus vulgaris & + & + & + & + & - \\
\hline 9 & Bacillus subtilis & + & + & + & + & + \\
\hline 10 & Yersinia species. & + & + & + & + & - \\
\hline
\end{tabular}

Table (7): Occurrence of fungal species isolated from different fast foods at $25^{\circ} \mathrm{C}$.

\begin{tabular}{|c|c|c|c|c|}
\hline \multirow[b]{2}{*}{ No. } & \multirow[b]{2}{*}{ Isolated fungal species } & \multicolumn{3}{|c|}{ Fast food } \\
\hline & & $\begin{array}{c}\text { Chicken } \\
\text { shawirma }\end{array}$ & Beef burger & $\begin{array}{c}\text { Flafel with vegetable } \\
\text { salads }\end{array}$ \\
\hline 1 & Aspergillus fumigatus & - & + & + \\
\hline 2 & Aspergillus niger & - & - & + \\
\hline 3 & Mucor species. & + & - & - \\
\hline 4 & Rhizopus nigricans & - & - & + \\
\hline 5 & Trichoderma species. & - & - & + \\
\hline 6 & Alternaria species. & + & - & + \\
\hline 7 & Penicillium species. & - & + & - \\
\hline 8 & Cladosporium species. & - & + & - \\
\hline
\end{tabular}

3.5.4.Gram positive nonsporing irregular rods: Microbacterium species, isolated from traditional foods only.

3.5.5.Gram-positive rods and cocci (endospores): Isolated from traditional foods and fast foods. It was noticed that the samples of traditional foods included many bacteria not isolated from the samples collected from fast foods such as

Clostridium perfringens, Acetobacter species, Bacillus coagulans, Erwinia carotovora, Flavobacterium species, Klebsiella pneumoniae, Lactobacillus plantarum, Luconostoc mesenteroides, Microbacterium lacticum. Micrococcus species, Pseudomonas fluorescens, Pseudomonas putrefaciens, Streptococcus, lactis, Streptococcus thermophilus and Achromobacter species.

Matching the results recorded in Table (1) with the results recorded in Table (4), it was noticed that many species of pathogenic bacteria were isolated from traditional foods and fast foods causing many diseases for human.

The total count of bacteria was the highest in
Flafel with vegetable salad samples follow by beef burger sample and the bacterial count was lower in chicken shawirma samples (Table 9).

3.6.Isolation of fungi:A-From traditional food Isolation and identification of fungi were performed and those included Alternaria species, Aspergillus niger, Aspergillus glaucus, Cheotomium candidium, Cladosporium herbarum, Fusarium species, Monilia species, Mucor rouxii, Neurospora species, Penicillium expansum, Penicillium species, Rhizopus nigricans, Sporotrichum carnis and Thamnidium elegans (Table 2).

B- From fast foods: The fungi isolated from fast food samples included Alternaria sp., Aspergillus fumigatus, Aspergillus niger, Cladosproium herbarum. Mucor species, Rhizopus nigricans, Trichoderma species, Penicillium sp. (Table 7).

(5) Isolation of yeasts from traditional foods: In the present study yeasts were isolated from traditional food samples and included Saccharomyces rouxii, Torulopsis caroliniana and Zygosaccharomyces sp. as shown in Table (3). 


\section{DISCUSSION}

The effect of microorganisms on human health has been reported. The present study was performed in Saudi Arabia (2007) to give information of the distribution and presence of pathogenic microorganisms in traditional and fast foods from different restaurants. This is important to human and to discuss their role in the food poisoning and also the causation of many human diseases. Studies on the isolation of pathogenic bacteria, fungi and yeasts in this investigation indicated that some Gram negative and Gram positive bacteria were found and recorded in Tables $(1 \& 4)$. Bacteria of the greatest importantce to human pathology are the most common causes of human infection and extensively widespread in the environment using fast foods. Our results are in agreement with those of Kay et al. (1994). Their findings are consistent with our results that revealed some pathogenic bacteria, fungi and yeasts in fast and traditional foods. Most investigators indicated that bacteria, fungi and yeasts may exert their pathogenic action either through infection of the body, or as a source of toxic substances demonstrated in contaminated foods. The most common infections causing food poisoning and other diseases are those associated with contaminations due to fast and traditional foods (Kay et al., 1994).

More recent studies have focused attention on the food poisoning diseases due to several pathogenic microorganisms. Many human diseases are associated with contamination of fast and traditional fast foods. Many workers reported that raw food, especially meat, poultry and sea food, as well as their juices, can contain dangerous microorganisms, such as Salmonella, Campylobacter, Listeria and Escherichia coli, which may be transferred into other foods during food preparation and storage (Uyttendaele et al., 1999). Our work is in agreement with the above studies. In raw milk, the presence of lactic acid producing bacteria, under suitable conditions ferments the lactose present to lactic acid. The increasing acidity in turn prevents the growth of other organisms, or slows their growth significantly. During pasteurization however, these lactic acid bacteria are mostly destroyed (Christison and Ivany, 2006). These results are in agreement with our results.

Feng et al. (2007) reported that some microorganisms are harmful and cause disease while others are benevolent neutral, or even helpful (e.g., Streptococcus lactis to make butter milk and break down toxins in our environment, while others can sick us (e.g., contaminants in food like Escherichia coli or Salmonella), or can kill us for example,
Table (8): Total viable counts (cfu/gm) of bacteria counted in traditional samples.

\begin{tabular}{|c|c|c|}
\hline No. & Sample & $\begin{array}{c}\text { Total viable count } \\
\text { (Log 10 cfu/gm) }\end{array}$ \\
\hline 1 & Jarish & 5.20 \\
\hline 2 & Mataziz & 5.07 \\
\hline 3 & Qursan & 5.20 \\
\hline 4 & Keshta & 1.02 \\
\hline 5 & Mathabib & 5.38 \\
\hline 6 & Freek & 0.94 \\
\hline 7 & Hunayni & 5.15 \\
\hline 8 & Saliq & 0.94 \\
\hline 9 & Harees & 0.59 \\
\hline
\end{tabular}

cfu: colony forming unit

Table (9): Total viable counts (cfu/gm) of bacteria counted in fast food samples.

\begin{tabular}{|c|c|}
\hline Type of sample & $\begin{array}{c}\text { Total count of } \\
\text { bacteria }(\mathbf{L o g} \\
\mathbf{1 0} \mathbf{~ c f u / g m})\end{array}$ \\
\hline Chicken shawarmas & 5.28 \\
\hline Beef burger & 5.53 \\
\hline $\begin{array}{c}\text { Flafel with vegetable } \\
\text { salads (lettuce, } \\
\text { tomato, cucumber) }\end{array}$ & 5.76 \\
\hline
\end{tabular}

Proteus cause amoebic dysentery, fungi cause athelete's foot and ringworm, bacteria cause pneumonia, legionmaire's disease, Streptococcus throat, tetanus and other diseases.

Some animal disease bacteria can cause human diseases with close animal-man contact. Some of these are Brucella, enteropathgoenic E. coli, Corynebacteria, Mycobacterium, Leptospira, Coxiella burnetii and Clostridium tetani. Heaton and Jones (2008) suggested that coliforms, E. coli, enterococci, $S$. aureus, $C$. perfringens and Salmonella are often present on fresh tissues since slaughter process does not include a bacterial step. The frequency and levels of these bacteria will vary, depending upon farm, climatic, and processing conditions.

Recent studies indicated that Staphylococcus aureus, Clostridium perfringens, and Salmonella frequently are present in low numbers on raw meat surface Clostridium botulinum occurs infrequently.

As shown in Table (10) pathogenic bacteria, important diseases and prevention of each disease were recorded to indicate the possible causative 
Table (10): Pathogenic bacteria, important diseases and prevention of each disease (bacteria isolated from fast and traditional foods)

\begin{tabular}{|c|c|c|c|}
\hline Organism & Where they be found & Important diseases & Prevention \\
\hline Campylobacter jejuni & $\begin{array}{l}\text { Contaminated drinking water and unpasteurized milk, } \\
\text { contaminated food, with incorected prepared meat and poultry }\end{array}$ & $\begin{array}{l}\text { Human gastroenteritis in the world, food } \\
\text { poisoning, abdominal pain diarrhea, fever, and } \\
\text { malaise }\end{array}$ & $\begin{array}{l}\text { Treated with antibiotics in severe cases such } \\
\text { as ciprofloxacin, erythromycin, } \\
\text { azithromycin or norfloxacin }\end{array}$ \\
\hline Escherichia coli & $\begin{array}{l}\text { Food or water or with the individuals handling the infant's } \\
\text { child, unwashed vegetables or undercooked meat, raw ground } \\
\text { beef, raw seed sprouts, raw milk, unpasteurized juice, and } \\
\text { foods contaminated, by infected food workers via fecal-oral } \\
\text { route. Found in recreational waters and its presence is used to } \\
\text { indicate the presence of recent fecal contamination }\end{array}$ & $\begin{array}{l}\text { Most E. coli strains are harmless, but some can } \\
\text { cause serious food poisoning in humans, and are } \\
\text { occasionally responsible for product recalls, the } \\
\text { harmless strains are part of the normal flora of } \\
\text { the gut. Produce potentially lethal toxins, food } \\
\text { poisoning, diarrhea in humans, rabbis, dogs, cats } \\
\text { and horses, urinary tract infections }\end{array}$ & $\begin{array}{l}\text { Cooking food property, preventing cross- } \\
\text { contamination instituting barriers such as } \\
\text { gloves for food workers, pasteurization of } \\
\text { juice or dairy products and proper hand } \\
\text { washing requirements treated with } \\
\text { antibiotics. }\end{array}$ \\
\hline Listeria monocytogenes & $\begin{array}{l}\text { Foods as raw milk, pasteurizede fluid milk, cheeses, ice cream, } \\
\text { raw vegetables, fermented raw meat sausages, raw and cooked } \\
\text { poultry, raw meats (of all types), and raw and smoked fish and } \\
\text { refrigerated foods. Isolated also from soil and silage. }\end{array}$ & $\begin{array}{l}\text { It is the causative agent of listeriosis. It is one of } \\
\text { the most virulent food borne pathogens with } \\
\text { fatality rates exceeding even Salmonella and } \\
\text { Clostridium botulinum. Gastrointestinal } \\
\text { symptoms such as nausea, vomiting, and diarrhea }\end{array}$ & $\begin{array}{l}\text { For gastrointestinal using antacids or } \\
\text { cimetidine. } \\
\text { May using also Vancomycin or Ampicillin } \\
\text { Alcohol as an effective topical sanitizer or } \\
\text { quaternary ammonium added to alcohol. }\end{array}$ \\
\hline Pseudomonas aeruginosa & $\begin{array}{l}\text { It is found in soil, water, skin flora, in normal atmospheres and } \\
\text { also in little oxygen. This bacterium is also found on and in } \\
\text { medical equipment including catheters, causing cross infections } \\
\text { in hospital and clinics }\end{array}$ & $\begin{array}{l}\text { It infects the pulmonary tract, urinary tract, burns } \\
\text { wounds, and also causes other blood infections, } \\
\text { gastrointestinal infection and external ear } \\
\text { infection }\end{array}$ & $\begin{array}{l}\text { Many antibiotics, for example, ear infections } \\
\text { or nail infections, topical gentamicin or } \\
\text { colistin may be used. }\end{array}$ \\
\hline Salmonella sp. & $\begin{array}{l}\text { It can be transmitted by humans to animals and vice versa. } \\
\text { Transmitted to humans by eating foods contaminated with animal } \\
\text { feces. Contaminated food such as beef, poultry, milk, or eggs, any } \\
\text { food including vegetables, food also become contaminated by the } \\
\text { hands of an infected food handler who did not wash hands with } \\
\text { soap after using the bathroom. The human pathogen of Salmonella } \\
\text { abdominals transmission by contact and infected food, water or fly. } \\
\text { Contamined foodstuffs. }\end{array}$ & $\begin{array}{l}\text { Diarrhea, fever, or abdominal cramps, food } \\
\text { poisoning. }\end{array}$ & $\begin{array}{l}\text { Food be heated for at least ten minutes at } \\
75^{\circ} \mathrm{C}\left(167^{\circ} \mathrm{F}\right) \text { so that the center of the food } \\
\text { reaches this temperature. It is not destroyed } \\
\text { by freezing. }\end{array}$ \\
\hline Staphylococcus aureus & $\begin{array}{l}\text { Part of the skin floral found in the nose and on skin. It presents } \\
\text { in prepared foods left too long at room temperature (e.g., } \\
\text { cooked hamburger, salads, dairy products). }\end{array}$ & $\begin{array}{l}\text { It can cause skin infections, pneumoniae, } \\
\text { meningitis osteom-yelitis, endocarditis, toxic } \\
\text { shock syndrome, bacteremia and septicemia, } \\
\text { food poisoning. }\end{array}$ & Treatment using penicillin, gentamicin \\
\hline Yersinia sp. & $\begin{array}{l}\text { Food products (especially vegetables, milk-derived products } \\
\text { and meat) }\end{array}$ & Gastroenteritis & $\begin{array}{l}\text { By oxidizing agents such as hydrogen } \\
\text { peroxide and potassium permanganate } \\
\text { solutions }\end{array}$ \\
\hline
\end{tabular}


factor (Richard et al., 2007; FDA Food, Drug Adminsitration, 2010).

These species are most hazardous when they grow without competition as in cooked foods (Talarico et al., 1997; Baumgart et al., 2007). Our results are also in agreement with the previous studies. The hazard potential from foods precooked in commercial establishment is high but the incidence of outbreaks has been low. The Center for Disease Control reported that although more than half of all food borne disease outbreak can be traced to meat and poultry products, there was a serious departure from good practices at the serving level (homes, restaurants, institutions) in nearly all instances. Baumgart et al. (2007) showed that the heating step in the production of cooked cured meats destroyes the typical raw meat flora except the spores. Salt and nitrite in the cure inhibit the growth of survivors and contaminats somewhat selectively. These agree with the results of this study (Table 9).

Ryan and Ray (2004) found that upon prolonged refrigeration, lactic acid bacteria, micrococci, enterobacteria, Bacillus, and yeast may grow and form slime. If the product is in a tight, gas impermeable package, the package may swell. Products of bacterial action sometimes combine with meat pigments to form a green color. Human contact may sometimes introduce a few Escherichia coli or Staphylococcus aureus. These results are in agreement with our results. The food bacteria associated with food fermentation are capable of producing different types of metabolites. They have antimicrobial properties (organic acids e.g., lactic, acetic propionic, aldehydes, ketones, and alcohols (ethanol, diacetyl and acetaldehyde), hydrogen peroxide, reuterine and bacteroides. It was reported that in the presence of the mesophilic lactic acid bacteria (e.g., Lactococcus lactis, some lactobacillus species, and Pediococcus sp.), the growth of psychrotrophic spoilage and pathogenic bacteria was reported to be controlled.

In refrigerated raw milk, meat, egg., and seafood, cells of Lactobacillus, Lactococcus and Leuconostoc species were added to control the growth of psychorotrophic spoilage bacteria such as Pseudomonas spp. The inhibitory property could be due to the release of antimicrobial compounds from the cells by the nonmetabolizing lactic acid bacteria.

It was reported that some strains of Lactobacillus reuteri, found in the gastrointestinal tract of humans and animals, produce a small molecule, reuterine that is antimicrobial against Gram-positive and Gram negative bacteria. It produces antibacterial action by inactivation some important enzymes, such as ribonucleotide reductase. Many strains of species from genera Lactococcus, Streptococcus, Leuconostoc, Pediococcus, Bifidobacterium, and Propionibacterium used in food fermentation have been reported to produce different bacteriocins (Daeschel and Panner, 1992).

Moreover, many of the organisms recorded in this study are in agreement with many researches, several yeast isolates normally present on the surface of fruits and vegetables were reported to prevent spoilage of the products by molds. Some of the inhibitory compounds are small proteins, while some others are enzymes. It was reported that cells of one such yeast isolate were found to adhere tightly with the mold mycelia and produce $\beta$-gluconase that degrades the cell wall of the molds and kills them. As many of these yeasts are normally present in fruits and vegetables that are eaten raw, they are not considered pathogenic and thus human may be sick when eat it or when used in salads in fast food or traditional food (Barnett et al., 2000).

Uzeh et al. (2009) showed that decay caused by molds and certain bacteria accounts for much of spoilage of fresh fruits and vegetables. Many of these organisms are true plant pathogens in that they can invade healthy plant tissue. While bacterial rot is caused mainly by genus Erwinia, numerous mold such as Alternaria, Botrytis, Phytophthora are responsible for a variety of market diseases. Our data are in agreement with the results obtained by Bichai et al. (2008) who showed that, the presence of Escherichia coli can be related to the use of polluted irrigation waters during growth,contamination through human handling, the use of contaminated containers, or washing after harvest with polluted water. It was suggested that it could increase the incidence of enteric pathogens (Angelillo et al., 2000). Thus products such as fresh or processed vegetables are the chapped salad ingredients (Lettuce, cabbage, carrots, tometo, cucumber....etc) sold in the grocery store and to the institutional trade (Kaneko et al., 1999a). These otained results are in agreement with those obtained by Ali and Shalaby (1999), who reported that biogenic amines are natural antinutrition factors and are important from a hygienic point of view as they have been implicated as the causative agents in a number of food poisoning episodes, and they are able to initiate various pharmacological reaction. Histamine, putrescine, cadaverine, tyramine, tryptam, Bphenylethylamine, spermine, and spermidine are considered to be the most important biogenic amines occurring in foods.

It was suggested that eating of fast food can lead to measurable signs of liver injury and inflammation. The plentiful availability of relatively inexpensive 
fat-and calorie-packed foods, has helped to make us the fattest. Fats which are commonly found in fast food have been shown in many tests to have a negative health effect on the body. It was suggested that fast food consumption has been shown to increase calorie intake, promote weight gain, and elevate risk for diabetes. A food may start with a $\mathrm{pH}$ which precludes bacterial growth but as a result of the metabolism of other microorganisms (yeasts or molds), $\mathrm{pH}$ shifts may occur and permit bacterial growth (Hathcox et al., 1995 and Robert et al., 2008).

The interplay of factors affecting microbial growth in foods such as (water activity, $\mathrm{pH}$, temperature) ultimately determines whether a microorganisms will grow in a given food. Often, the results of such interplay are unpredictable, as poorly understood synergism or antagonism may occur (Smith and Fratamico, 1995). Similar results were obtained by Richard et al. (2007) who reported that some pathogenic bacteria cause sickness for human. These bacteria such as: Listeria monocytogenes have been associated with such foods as raw milk, pasteurize fluid milk, cheeses, ice cream, raw vegtables, fermented raw-meat sausages, raw and cooked poultry, raw meats (of all types), and raw and smoked fish. Its ability to grow at temperature as low as $0^{\circ} \mathrm{C}$ permits multiplication in refrigerated foods. In refrigeration temperature $4^{\circ} \mathrm{C}$ the amount of ferric iron promotes the growth of L. monocytogenes (Dharmarha and Vaishali, 2009; Farber and Peterkin, 2009). Their results are in agreement with our results. Richard et al. (2007) showed that gastrointestinal disease has been reported by eating raw or inadequately cooked meat containing Bacillus spores. B. cereus causes food poisoning B. subtilis, B. coagulans were isolated from traditional food samples (Table 1) and (Table 4) from fast food samples of our study.

Campylobacter jejuni is widely distributed in nature, it infects the intestine, where it can cause ulcerative, inflammatory lesions in the jejunum, ileum, or colon. Diarrhea should be treated using fluids. Prevention is induced by good hygiene avoiding contaminated water, pasteurizing milk and milk products, and thoroughly cooking potentially contaminated food (e.g., poultry). C. jejuni was isolated from fast food samples only (Table 4). Clostridium perfringen is a part of the normal flora of the vagina and gastrointestinal tract. Its spores are found in soil. Acute food poisoning is caused by the generation of spores in improperly cooked food, resulting in the production of enterotoxin in the small intestine. It was isolated from traditional food samples (Table 1).

Feng et al. (2007) suggested that Escherichia coli is a part of the normal flora in the colon of human and other animals, but can be pathogenic both within and outside the gastrointestinal tract. Enterotoxigenic E. coli (ETEC), is a common cause of "traveler's diarrhea" in developing countries, it infects only humans, with transmission occurring through food and water contaminated with human waste, or by person to person contact, diarrhea can be prevented by taking precaution in food and water consumption, hand washing and disinfection. E. coli was isolated from traditional food samples (Table 1) and from fast food samples (Table 4). These results are in agreement with those obtained by AVI Biopharma (2008) who suggested that Pseudomonas aeruginosa often includes the production of both pyocyanin and fluorescein, as well as its ability to grow at $42^{\circ} \mathrm{C} . P$. aeruginosa is capable of growth in diesel and jet fuel, where it is known as a hydrocarbon-utilizing microorganism (or HUM bug), causing microbial corrosion. It creates dark gellish mats sometimes called "algae" because of their appearance. Several studies indicated that $P$. aeruginosa is the common cause of infections of burn injuries and of the external ear (otitis externa), and is the most frequent colonizer of medical devices (e.g., catheters). However, research indicates that salicylic acid can inhibit pyocyanin production (Prithiviraj et al., 2005). $P$. aeruginosa is widely distributed in nature (soil, water, plants, animals). $P$. aeruginosa can grow in distilled water, laboratory hot water baths, hot tubes, wet IV tubing, and other water containing vessels. This explains why the organism is responsible for so many nosocomial infections. This result is in agreement with our results. $P$. aeruginosa was isolated from traditional food samples and fast food samples (Tables 1 and 4).

To protect against Salmonella infection, it is recommended that food should be heated for at least ten minutes at $75^{\circ} \mathrm{C}\left(167^{\circ} \mathrm{F}\right)$ so that the center of the food reaches this temperature. Salmonella is not destroyed by freezing. It can survive several weeks in a dry environment and several months in water thus, they are frequently found in polluted water, contaminated from the excrement of carrier animals being particularly important (Administration Urged to Boost Food Safety, 2009; FDA/CFSAN-Food Safety, 2009). S. typhi is transmitted generally through food or water contaminated by human faeces. Public food handlers who are carriers can present a serious 
public health problem. Salmonella sp. was isolated from fast food samples (Table 4). Our results agree with the previous studies.

Staphylococcal gastroenteritis is caused by ingestion of food contaminated with toxin produced by Staphylococcus aureus superantigen. Some strains of $S$. aureus are capable of producing staphyloxanthin a carotenoid pigment that act as a virulence factor. It has an antioxidant action that helps the microbe to evade killing with reactive oxygen used by the host immune system. It is thought that staphyloxanthin is responsible for $S$. aureus characteristic golden colour (Clouditz et al., 2006). It was reported that emphasis on basic hand washing techniques are therefore effective in preventing the transmission of $S$. aureus. The use of disposable gloves by staff reduces skin-to-skin contact that therefore further reduces the risk of transmission.

Recent reports demonstrated that many researches showed that the introduction of Staphylococcus aureus into the blood stream can lead to various complications (Tables 1 and 4). Washing of hands and disinfection of fomites are important in the control of nosocomial Staphylococcus aureus epidermidis (Cosgrove et al., 2009). Streptococcus lactis, Streptococcus thermophilus were isolated from traditional food samples (Table 1).

Yersinia species is endemic distributed worldwide. Infection is transmitted by fleas, the organism can also be transmitted by ingestion of contaminated animal tissues, or via the respiratory route. $Y$. species was isolated from fast food samples (Table 4). Some members of Yersinia are pathogenic for humans, in particular, Y. pestis is the causative agent of the bubonic plaque. Rodents are the natural reservoirs of Yersinia, less frequently other mammals serve as hosts. Infection may occur either through blood (in the case of $Y$. pestis) or in an alimentary fashion, occasionally via consumption of food products (especially vegetables, milk-derived products and meat) contaminated with infected urine or feces (Ryan and Ray, 2004). These results are agree with our results. Yersinia may be associated with Crohn's disease, an inflammatory autoimmune condition of the gut by treatment and prevention by streptomycinis the drug of choice, gentamicin and tetracycline are acceptable alternatives.

For individuals in enzootic areas, efforts to minimize exposure to rodents and fleas is important. The above studies are in agreement with our research.
Barnett et al. (2000) reported that many mycotoxins found in various foods such as: Aspergillus toxins: (a) Aflatoxins: Aspergillus and Pencillium sp. have been reported to produce aflatoxins, and the aflatoxins have been isolated from legumes, grains, fruits, meats, spices, cheeses, milk, rice, corn, cotton seeds, others compounds with carcinogenic, hemorrhagic, heptaotoxic, neurotoxic and uterotrophic properties have been isolated from food stuff and identified as metabolites of fungi common to a variety of agricultural commondities (Shank et al., 1972). (b) Ochratoxins: these substances are a group of closely related compounds produced by Aspergillus ochraceus, A. sulphureus, and A. melleus. A. ochraceus group is common in soils and decaying vegetation, grains, wheat, corn, cotton seeds, legumes, peppers, onions and pears (Adams and Moss, 2000). (c) Sterigmatocystin: another common food contaminant is Aspergillus versicolor, A. nidulans, a compound bearing some structural resemblance to the aflatoxins in that, it produces liver and kidney damage and is like the aflatoxing a hepatocarcinogen (Stack and Rodricks, 1973). (d) Other Aspergillus toxins: there are numbers of other metabolites of this genus which have been shown toxic to animals, which are potential food contaminants.

Penicillium toxins: (a) Patulin: among the more important of the large number of mycotoxins produced by the penicillia is the potent antibiotic, patulin. Penicillic acid, rubrotoxin, and tremorgens and cyclopiazonic acid, that compounds elaborate a toxin and have potential carcinogenic agents (Harwig et al., 1973). (b) Rice toxins: Storage fungi proliferate in improperly stored rice. Most are of the genera Aspergillus and Pencillium, and about $10 \%$ of the isolates tested are toxigenic. The toxic effects of these substances interactions among them, and their natural occurrence have been reported (Saito et al., 1971). A polyenic compound called citreoviridin and an acidic compound known as citreomycetin. Some of these toxins affect the liver and kidney, some are neurotoxic.

Fusarium toxins: (a) Zearalenone, trichothecenes (diacetoxyscirpenol) and other toxigenic fungi, their potential for human health effects is probably realized by growth of Fusarium sp. It was reported that it is probably one of the more common mycotoxin contamination of food and feed (Pelczar et al., 2006). (b) Trichothecenes: There are mold metabolites which have structural features similar to those of the compound known 
as diacetoxyscirpenol. The acute toxicity of some of mycotoxin trichothecenes cause hemorrhage on the lip and mouth, throat, and entire gastrointestinal tract.

International Commission on Microbiological Specifications for Foods (ICMSF, 1996) reported that there are hundreds of fungal species which have been shown to be toxigenic from animal feeds, peanuts, and seeds, flour, spaghetti, black and red peppers. The following genera showed toxic isolates: Alternaria; Cheotomium, Cladosporium, Curvularia, Gliocladium, Rhizoctonia, Scopulariopsis, Trichoderma, Trichothecium. Pithomyces chartarum produce mold metabolites known as sporidesmins and Rhizoctonia leguminicola produce Slaframine causing diarrhea for animals. Also, suggested that control of fungal toxin production can be controlled by the adjustment of $\mathrm{pH}$, water activity, and temperature control. Temperature does not protect from all toxigenic molds, however, for many will grow at refrigeration temperatures. ICMSF found several toxigenic species capable of growth and toxin production at temperatures down to $10^{\circ} \mathrm{C}$. There is evidence that some strains may be more toxigenic at low temperatures than at optimum growth temperatures. Adjustment of water activity, is the best means of controlling growth of microorganisms in foods. e.g., Campylobacter cells when ingested with food or water, it enters the host intestine via the stomach and colonize the distal ileum and colon. The most effective means of eliminating human exposure to mycotoxins in foods is by the prevention of toxin formation. This requires agricultural and industry practices designed to reduce the opportunity for fungal growth from harvest to ultimate commodity use.

In conclusion, the need for good hygienic practices, proper handling, storage and retail of salads in clean environment and at refrigeration temperature can not be over emphasized to ensure good quality and safe salads.

Prevention of mycotoxins must become a cooperative effort on the part of all involved in food production.

We can also conclude that if people have meals regularly and in suitable quantities, there will not be any health problems, relating habits concerning to nutrition according to what the healthy nutritional experts specify, if all the society follow right nutritional habits, healthy foods, they have health.

\section{REFERENCES}

Adams M.R. and Moss M.O. (2000). Food microbiology R Soc Chem Sci Park Cambridge P 447.

Administration Urged to Boost Food Safety Efforts. Washington Post (2009). Among them is a final rule, issued by the FDA, to reduce the contamination in eggs. About 142.000 Americans are infected each year with Salmonella enteritidis from eggs, the result of an infected hen passing along the bacterium.

Ali R. and Shalaby M. (1999). Significance of biogenic amines to food safety and human health. Food Technology and Dairy Science, Cairo, Egypt.

Angelillo I.F., Viggiani N.M, Rizzo L. and Bianco A. (2000). Food handlers and food borne disease: knowledge, attitude sand reported behavior in Italy. J Food Prot., 63: 381-385.

Arx J.A. Von (1981). Systematic of conidial yeasts, (in) biology of conidial fungi. Vol. 1 (eds). TT Cole and B. Kendrick Academic Press, New York pp. 85-96.

Atlas R.M. (1993). Handbook of mcirobiolgoical media. Lawrence C. Purks, CRC Press. Boca Raton, Ann Arbor, London, Tokyo, 196: P. 666, 798.

AVI Biopharma (2008). Antisense antibacterial method and compound. World Intellectual Property Organization.

Barnett J.A., Payne R.W. and Yarrow D. (2000). Yeasts: characteristics and identification, $2^{\text {nd }}$ ed. Cambridge University Press, Cambridge, United Kingdom, 255pp.

Barrow G.I. and Feltham R.K.A. (1993). Cowan and Steel's Manual for the identification of medical bacteria, $3^{\text {rd }}$ edn., Cambridge University Press, Cambridge, 331pp.

Baumgart M., Dogn B. and Rishniw M.(2007). Cutlure independent analysis of ileal mucosa reveals a selective increase in invasive Escherichia coli of novel phylageny relative to depletion of Clostridiales in Crohn's disease involving the ileum. ISME J 1(5): 403-18.

Bichai F., Payment P. and Barbeau B. (2008). Protection of water borne pathogens by higher organisms in drinking water: a review. Can J Microbiol., 54(7): 509-524

Canadian Institute for Health Information (2007). The adult obesity rate almost tripled between (1985-2001) to about 15 percent.

Centers for Disease Control and Prevention (2001). Preliminary food net data on the incidence of 
foodborne illnesses selected sites. United States, Morb Mortal Wkly Rep 50: 241-246.

Cheesbrough M. (1984). Microbiological examination of specimens and biochemical testing of microorganisms in: Medical laboratory manual of tropical countries. $1^{\text {st }}$ edition. Volume 2. Tropical Health Technology, Butterworth Heinemann Ltd. Printed in Great Britain At University Press, Cambridge, p. 2639, 57-69s.

Christison G.W. and Ivany K .(2006). Elimination diets in autism spectrum disorders: any wheat amidst the chaff $\mathrm{J}$ Dev Behav Pediator, 27: p.162.

Clouditz A., Resch A., Weiland K.P., Peschel A. and Gotz F. (2006). Staphylococcus plays a role in the fitness of Staphylococcus aureus and its ability to cope with oxidative stress. Infection and immunity, 74(8): 4950-4953.

Collins C.H., Palricia M.L. and Grange J.M. (1995). Microbiological methods. $7^{\text {th }}$ edition, Butterworth Heinemann Linacre House Jordan Hill, Oxford, p.493.

Cosgrove S.E., Vigliani G.A. and Campion M. (2009). Initial low dose gentamicin for Staphylococcus aureus bacteremia and endocarditis is nephrotoxic. Clin. Infect. Dis., 48(6): 713-721.

Daeschel M.A. and Panner M.H. (1992). Hydrogen peroxide lactoperoxide systems, and reuterine, in food Biopreservative of microbial origin, Baco. Raton., FL, 155.

Deak T. and Beuchat L.R. (1996). Handbook of Food Spoilage Yeasts. CRC Press, Inc., New York.

De Boer E. and Hahne M. (1990). Cross contamination with Campylobacter jejuni and Salmonella spp. from raw chicken products during food preparation. J Food Prot., 53: 10671068.

Dharmarha V. and Vaishali G. (2009). The majority of deaths from Listeria food poisoning are in individuals with compromised immune systems: pregnant women, newborns, the elderly, the immunosuppressed. "A focus on Listeria monocytogenes". National agricultural library, food safety research information office.

Domsch K.H., Gams W. and Anderson T.H. (1993). Compendium of soil fungi, Vol. 1 Academic Press, London.

El-Sherif A.M., Khalafalla F.A. and Darwish A.M . (1991). Microflora in beef burger sandwiches. J Egypt Vet. Med. Ass., 51: 169-177.
Farber J.M. and Peterkin P.I. (2009). Listeria monocytogenes a food borne pathogen. Microbiol Rev., 55: 476-511.

FDA/CFSAN-Food Safety (2009). Safety A to Z Reference Guide-Salmonella FDA-Center for Food Safety and Applied Nutrition.

FDA Food Drug Administration (2000). Food code recommendation of the United States Public Health Service. FDA. Washington, DC. USA.

FDA Food Drug Administration (2010). Food code recommendation of the United States Public Health Service. FDA. Washington, DC. USA.

Feng P., Weagant S. and Grant M. (2007). Enumeration of Escherichia coli and the coliform bacteria. Bacteriological Analytical Manual ( $8^{\text {th }}$ ed.). FDA/Center for Food Safety and Applied Nutrition.

Finegold S.M. and Martin W.J. (1982). Enterobacteriaceae and non fermentative Gram negative bacilli. In Bailey and Scott's Diagnostic Microbiol. Finegold, SM and Martin WJ (eds). $6^{\text {th }}$ edition CV Mosby Company, St-Louis. Toronto London, p.199-239 and 249-265.

Harwig J., Chen Y.K., Kennedy B.P.C. and Scott P.M. (1973). Occurrence of patulin and patulin producing strains of Penicillium expansum in natural rots of apple in Canada. Can. Inst. Food Sci. and Technol., J. 6: 22-25.

Hathcox A.K., Beuchat L.R and Doyle M.P. (1995). Death of enterochemorrhagic Escherichia coli 0157: H7 in real mayonnaise and reduced calorie mayonnaise dressing as influenced by initial population and storage temperature Appl. Environ. Microbiol., 61: 4172-4177.

Heaton J.C. and Jones K. (2008)."Microbial contamination of fruits and vegetables and the behaviour of enteropathogenic in the phyllosphere". Appl. Microbiol., 104(3): 61326.

ICMSF (1996). International Commission on Microbiological Specifications for Foods. Microorganisms in foods. 5 microbiological specifications of food pathogens. Clays Ltd, St Ives Plc, Bungay Suffolk, U.K.

John I.P. and Pitt I. (1979). The genus Penicillium and its telomorphic states.

Kaneko K., Hayashidani H., Ohtomo Y., Kosuge J., Kato M., Takahashi K., Shiraki Y. and Ogawa M. (1999a). Bacterial contamination of ready to eat foods and fresh products retail shops and food factories. J Food Prot., 62: 644-649.

Kaneko K., Hayashidani H., Ohtomo Y., Kosuge J., Kato M., Takahashi K., Shiraki Y. and Ogauwa 
M. (1999b). Bacterial contamination of ready to eat foods and fresh products in retail shops and food factories. J. Food and Drug Analysis, 1: 105-115.

Kao W. and Shih D.Y. (1993). Survey of Staphylococcus aureus in vegetable salad. J Food and Drug Analysis, 1: 105-115.

Kay B.A. Griffin P.M., Stockbine N.A. and Wells J.G. (1994): Too fast food bloody diarrhea and death from Escherichia coli 0157: H7. Clin Microbiol Newsl., 16: 17-19.

Krieg N.R. and Holt J.G. (1984). Bergey's Manual of Systematic Bacteriology, Williams and Wilkins, Baltimore, P.141-214.

Laner E. and Kandier O. (1980). Lactobacillus grasseri, sp. N.V., a new species of the subgenus thermobacterium. Zbl Bakt 1. Abt. Orig., (1): 75-78.

MacGowan A.P., Bowker R. and Mclauchlin J. (1994). The occurrence and seasonal changes in the isolation of Listeria spp. in shop bought foodstuffs, human faeces, sewage and soil from urban sources. J Food Microbiol., 21: 325-334.

Makukutu C.A. and Guthrie R.K. (1986). Survival of Escherichia coli in food at hot holding temperature. J Food Prot., 49: 497-499.

Matthews K.R., Roberson J., Gillespie B.E., Luther D.A. and Oliver S.P. (1997). Identification and differentiation of coagulase negative Staphylococcus aureus by polymerase chain reaction. Journal of Food production 60(6): 686688.

Meng J. and Doyle M.P. (1998). Emerging and evolving microbial foodborne pathogens. Bull Inst Pasteur, 96: 151-164.

Norberg P. (1981). Enteropathogenic bacteria in frozen chicken. App. Environ. Microbiol., 42: 32-34.

Ockerman H.W. and Stec. J. (1980). Total plate and coliform counts for fast food service sandwiches J Food Sci., 45: 262-266.

Odumeru J., Mitchell S., Alves D., Lynch J., Yee A., Wang S., Styliadis S .and Farber J. (1997). Assessment of the microbiological quality of ready to use vegetables for health care food services. J. Food Prot., 60: 954-960.

Oxoid J.A. (1992). The Oxoid Manual. Oxoid Ltd, Basing stoke, Hampshire, U.K.

Pacini R., Quagli E., Galassi R., Tozzi E., Malloggi L. and Marinari M. (1997). Staphylococcus aureus isolated from asymptomatic carriers, food handlers, in the livorno Area. Igiene Moderna 107: 45-53.
Pelczar M.J., Chane C.S. and Kreig N.R. (2006). Microbiology $5^{\text {th }}$ edition. Tata McGraw-Hill Publishing Company Limited, New Delhi.

Petersen K.E and James W.O. (1998). Agents, vehicles and casual inference in bacterial foodborne disease outbreaks. J Am. Vet. Med. Assoc., 212: 1874-1881.

Prithiviraj B., Basis H., Weir T., Suresh B., Najarro E., Dayakar B., Schweizer H. and Vivanco J. (2005). Down regulation of virulence factors of Pseudomonas aeruginosa by salicylic acid attenuates its virulence on Arabidopsis thaliana and caenorhabditis elegans, Infect Immun., 73(9):5319-28.

Richard A, Harvey Pamelo C. and Champe M. (2007). Lippincott illustrated reviews, Second Edition.

Robert A., Wascher M.D and FACS (2008). Fast food's effects on your liver. Journal Gut, Sweden. 89:491-498.

Ryan K.J. and Ray C.G. (2004). Sherris Medical Microbiology (4 ${ }^{\text {th }}$ ed.). McGraw Hill.

Saito M., Enomoto M. and Tatsumo T. (1971). Yellow rice toxins. Leuteoskyrin and related compounds, Chlorine containing compound and citrinin. Microbial toxins, Vol. VI, Fungal Toxins. A Ciegler S. Kadis SJ, Ajl, editors, Academic Press, New York.

Sanchez C. (2009). Lignocellulosic residues: Biodegradation and bioconversion by fungi. Biotechnology Advances, 27: 185-194.

S.A.S Institute (1988). SAS user's guide. SAS Institute Inc., Carry, NC, USA.

Shank R.C., Wogan G.N. and Gibson J.B. (1972). Dietary aflatoxins and human liver cancer. 1 Toxigenic molds in foods and foodstuffs II. Aflatoxins in market food and foodstuffs of Thailand and Hong Kong. Food and Cosmetic Toxicology, 10: 51-70.

Smith J.L. and Fratamico P.M. (1995). Factors involved in the emergence and persistence of foodbrone diseases. J. Food Prot., 58: 696-708.

Sneath P.H., Mair N.S. and Sharp E. (1989). Bergey's manual of systemic bacteriology. Williams and Wilkins, Baltimore, USA. Vol.2: p. 999-1071.

Stack M.E. and Rodricks J.V. (1973). Collaborative study of the quantitative determination and chemical confirmation of sterigmatocystin in grains. J Assoc of Official Analyt. Chem., 56: p. 1123-1126.

Swanson K.M., Busta F.F., Peterson E.H. and Johnson M.G. (1992). Colony count methods. In 
C. Vanderzant and F. Spilitstoesser (eds) Compendium of methods for the microbiological examination of foods. American Public Health Association, Washington, DC. USA p. 75-95.

Talarico F., Roccia E. and Nero D. (1997). Pevalnece of enterotoxigenic Staphylococcus in food handlers in the province of Catanzaro (Italy). Igiene Moderna,107: 137-142.

Uyttendaele M., De Troy P. and Debevere J. (1999).Incidence of Salmonella, Campylobacter jejuni, Campylobacter coli and Listeria monocytogenes in poultry carcasses and different types of poultry products for sale on the Belgian retail market. J Food Prot., 62: 735740 .
Uzeh R.E., Alade F.A. and Bankole M. (2009).The microbial quality of pre-packed mixed vegetable salad in some retail outlets in Lagos, Nigeria. African J of Food Science, 3(9): p. 270-272.

Wart A.D. (1989). Relationships between the resistance of yeasts to acetic, propionic and benzoic acids and to methyl paraben and $\mathrm{pH}$. Int. J. Food Microiol., 8: 343-349.

Woodward B.B.(1996). Food and residue laboratories. Sited in Lim, C.S.Y. Fernando and Wei C. (1996). Occurrence of Listeria monocytogenes, Salmonella spp., Escherichia coli and E. coli 0157: H7 in vegetable salads. Food Control, 7: 135-140.

\section{محتوى الوجبات السريعة والثعبية من الميكرويات سعدية محم حسانين عيسى}

قسم الميكروبيولوجى - كلية العلوم - جامعة عين شمس - القاهرة - مصر

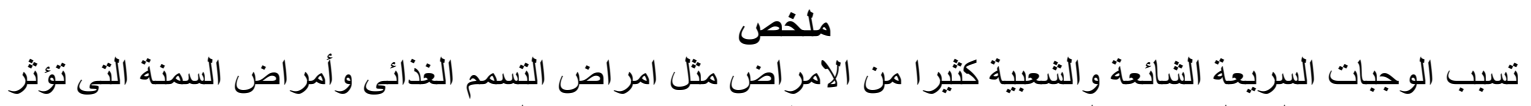

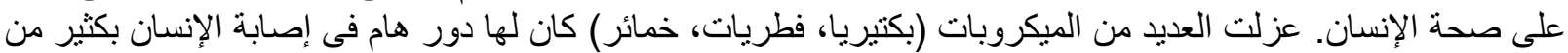

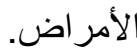

إستهدفت الدر اسة الحالية معرفة أنواع الميكروبات المتو اجدة فى الوجبات السريعة عن طريق عزلها وتنقيتها وتعريفها

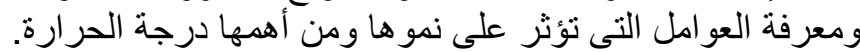

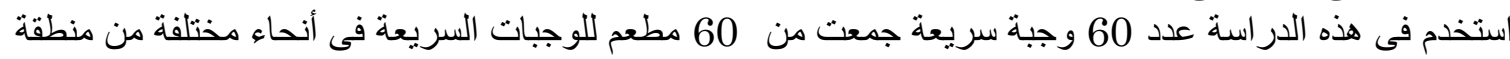

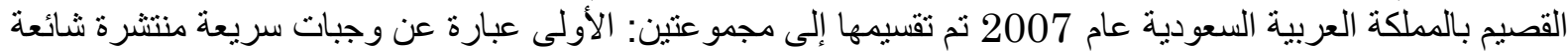

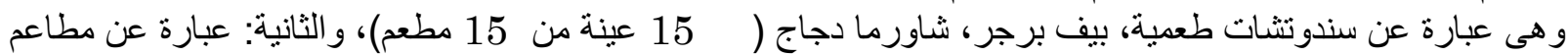
للوجبات الشعبية السريعة (45 عينة من 45 مطعم) وهى عبارة عن جريش، مطازيز، كرسان، قشطة، مصايبي، فريك، حنينى، سليق، هريس.

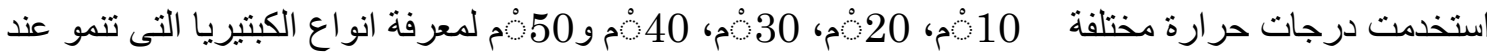

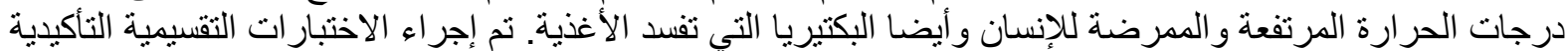
باستخدام أشرطة API 20E, bio Merieus, 2010) API لتعريف البكتيريا. تم استخدام الطرق والإنة الاختبار ات التأكيدية

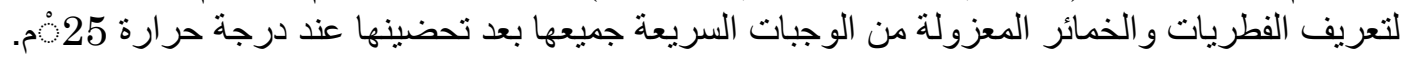

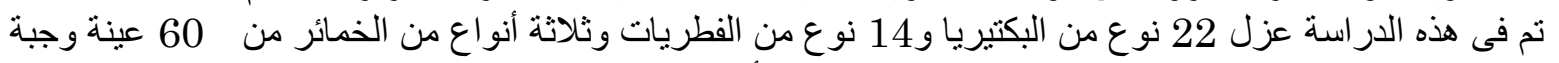

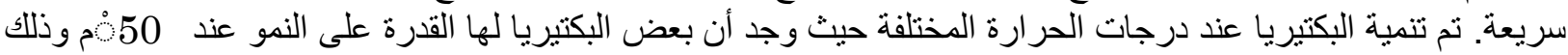
يسبب فساد للوجبات السريعة. أثنتت النتائج أن 9 أنو اع من البكتيريا محبة للحر ارة حيث أمكنها النمو عند درجة حرارة 50 مْم.



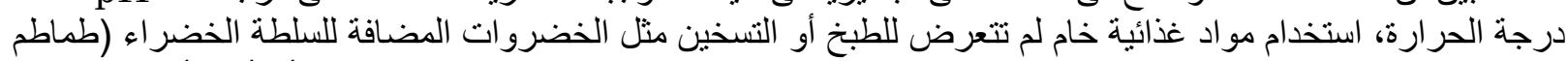

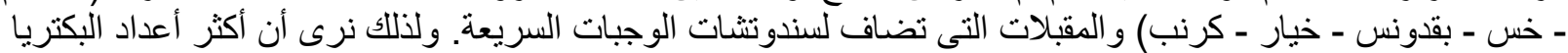

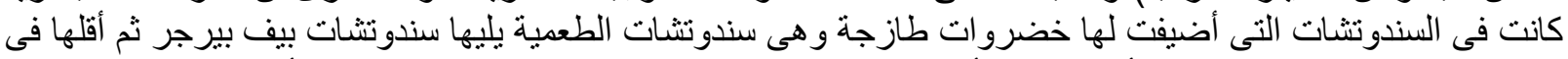

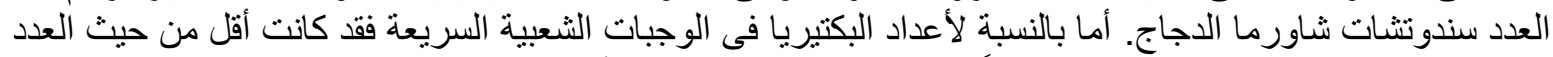

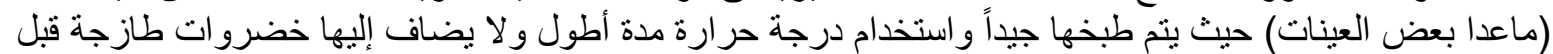

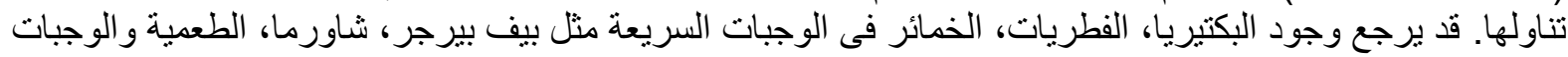




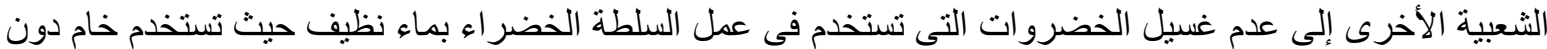

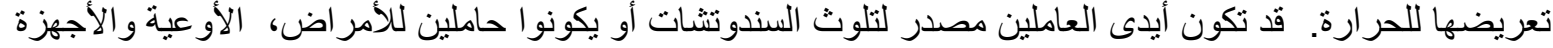

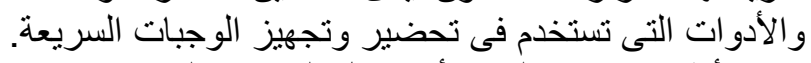

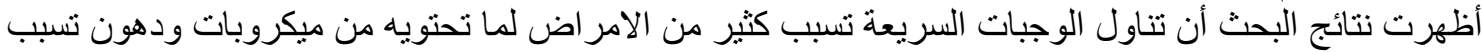

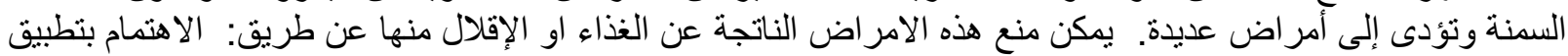

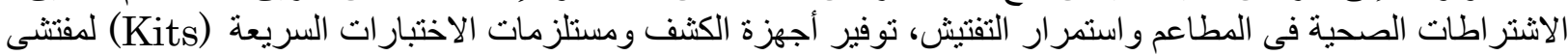

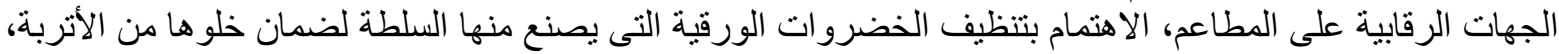

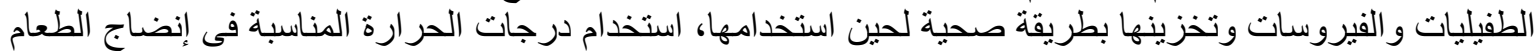

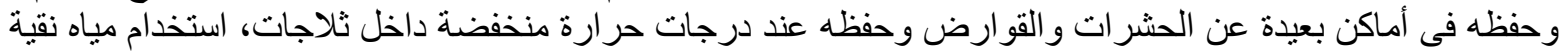

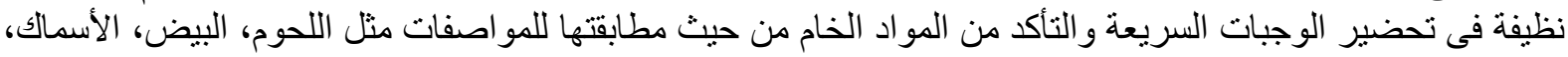
عدم ترك الوجبات السريعة مدة طويلة فى درجة حرارة الجو وخاصة التى تحتوى على مو اد غذائية حيو انية وبخاصة فى الصى فصل الصيف.

المجلة العلمية لكلية الزراعة - جامعة القاهرة ـ المجلد (62) العدد الثانى (ابريل2011):244-226. 